\title{
THE HISTORY OF MEDICINE IN INDIA AND BURMA*
}

by

M. S. RAO

THE study of the history of ancient Indian medicine in the Indian sub-continent as a special subject by practitioners of modern medicine, is of comparatively recent origin; some eminent Indian physicians, however, have interested themselves in the subject and have published short articles in the Indian medical press from time to time. Notably one or two have recently published small treatises on Indian medicine in English.

In order to give a reasonably clear picture of the progress of medical science in the Indian sub-continent, I would like to present the subject under the following four main divisions. Each main division has several sub-headings:

(I) Ancient Indian medicine; (II) Indian medicine in medieval times; (III) Indian medicine during the nineteenth century and the first half of the twentieth century; (IV) Progress after Independence in India (1947 to date).

\section{ANCIENT INDIAN MEDICINE}

Prehistoric times: This is the period pertaining to all peoples of the Indian subcontinent from the Stone Age to the time when written history begins in the third and second millenia B.C. with the Indus Valley civilization. The script of those times is yet to be deciphered. With the Aryan Invasion of India about 1500 B.C., the Vedic period of the Indian system of medicine may be said to have begun.

Thus the origin of the Indian system of medicine goes back to several centuries before the birth of Christ. From time immemorial religious and other teachings and philosophy of life propounded by the ancients of the Indian sub-continent are contained in the earliest sacred books of unknown antiquity, called the Vedas. The Vedas are four in number, viz. Rigveda, Samaveda, Yajurveda and Atharvaveda. They were handed down by teachers to pupils by word of mouth throughout the ages. The teachers were enlightened sages called Rishis and their teachings are believed to be words of God expressed through these Rishis. The Indian system of medicine is said to have roots in the Vedas.

The term Ayurveda was given to the ancient Indian system of medical sciences, which literally means knowledge of life. Ayurveda is strictly not a Veda like the four Vedas. The origin of Ayurveda is also uncertain. This is believed to have a divine origin, and there are different versions as to how they were divinely revealed to the ancient sages. The Ayurveda is considered to be a branch of the fourth Veda, the Atharvaveda. This would thus give it divine authority.

The progress in history, down the centuries, of medical sciences in the Indian

- A paper read at the Symposium on The History of Medicine in the Commonwealth, organized by the Faculty of the History of Medicine and Pharmacy, and held at the Royal College of Physicians of London on 23 September 1966. 


\section{History of Medicine in India and Burma}

sub-continent is somewhat difficult to follow accurately. The teachings of Ayurvedic medicine have been pieced together from the ancient religious books and other literature, but mostly from the writings of Charaka the Physician, and Sushruta the Surgeon. They are believed to have lived about 300 B.c. Two monumental treatises called Charaka Samhita and Sushruta Samhita, written by these medical men, form the basic treatises even to this day, for practitioners of the Ayurvedic system of medicine in India. Madhava nidhana and Ashtanga hridaya are two other important works on Ayurvedic medicine, published at a later period. Vaghbhata I and Vaghbhata II are other authors of the time frequently quoted. It would appear from the research work of various authors, that the development of Ayurveda was coeval with the evolution of the culture and civilization of the Indian sub-continent.

Much of the origin of Ayurveda is steeped in mythology. An account of these mythological ramifications involving the use of innumerable Sanskrit names and words, can scarcely appeal to or register with British readers. I have therefore doliberately avoided using them except where absolutely necessary.

Leaving aside its legendary origin, from recorded history Ayurveda had attained a high stage of development during the period of Atreya, i.e. 1500 B.c. Knowledge flowing from different specialized fields of fundamental and applied sciences were already integrated and general principles evolved. The concept of man in his entiretyphysical (including chemical), and biological (including psychological and the spiritual that composes Man)-became the basis for the study of medicine. By this time, medical science had already developed eight specialized branches, namely:

(1) internal medicine (kayachikitsa); (2) paediatrics (kumarabhritya); (3) psychotherapy (bhutavidya); (4) oto-rhino-laryngology (urdhwanga chikitsa); (5) general surgery (shalya tantra); (6) toxicology (agada tantra); (7) geriatrics; (8) the science of virility (vajikarana).

For the proper study and practice of these different specialized branches of medicine, a good training in certain basic subjects formed the essential ingredients. These were: (a) anatomy, including dissection, and physiology (sharira vritti); (b) aetiology (hetu); (c) pathology and pathogenesis (vyadhi); (d) therapeutics (karma); (e) objectives (karya); (f) climatology (kala); (g) pharmacology (karana); (h) medical and surgical procedure (vidhi).

A methodology for science in general existed at that time and these principles were rigidly applied to medical science, in common with the philosophy of natural sciences. These were: (a) direct observation (pratyaksha); (b) testing of the validity of observed facts (anumana); (c) analysis of the facts observed (yukti); (d) testimony of experts (aptopadesha).

Evidence is also available about the utilization of statistics as a method for the determination of truthful knowledge. The old masters insisted on scientific methodology, so that false knowledge and wrong conclusions may be rejected.

The Ayurvedic system of medicine was based on the system of 'Tridosha'-the three doshas-kapha, vaata and pitta, existing in a balanced proportion in health. A disturbance in this balance resulted in disease with its attendant ailments. This fundamental concept finds different interpretations of symptomatology. Thus flatulence is due to preponderance of vaata, as also pains of rheumatic origin. Headaches 


\section{S. Rao}

are due to pitta, and so on. Even to this day, these beliefs are held by the average person in India. On this assumption articles of food and medicines are classified according to a similar terminology. Food and drugs are also divided according to their 'cooling' or 'heating' effects. In the treatment of diseases, according to the Ayurvedic system of medicine, observance of a diet regime is a very essential part of treatment. A patient accepting the modern system of therapy, would still seek instruction on all these points from the treating physician. Peculiar to Ayurveda is this concept to explain the actions of foods and drugs on the human system. Descriptions of diseases, their classification, methods of diagnosis and treatment were laid down. Nutrition, exercise, hygiene and means of prevention of disease were dealt with. A large number of herbal medicines of indigenous origin formed the materials of treatment. The use of the plant containing ephedrine for the relief of asthma was known. The root of Sarpagandha (Rauwolfia serpentina) was used in mental disorders. Jatamansone in the treatment of cardiac diseases, punarnava, which is a favourite herbal remedy for chronic renal failure with modern physicians in India, were also known to ancient Indian physicians. Such examples can be multiplied indefinitely. This was followed by 'Rasa period', when minerals were used; thus iron, zinc, copper, lead, gold and mercury were used in therapeutics.

The surgical and allied branches in the Ayurvedic system of medicine, became highly specialized. Over 121 instruments and appliances of various sorts were accurately described. These included knives, scissors, syringes, hooks, forceps, trocars, needles, etc. From a detailed description of the appliances, modern medical research workers have been able to recognize the instruments as such. Medical students were instructed in the use of these. Operations for anal fistula, tonsillectomy, amputations and excisions, couching of cataract, obstetric procedures, venesection, ligation of blood vessels were all described and taught to students. Trephining of the skull and eye operations were also described. The father of surgery in those days was Sushruta, who lived about 300 B.C. He wrote several volumes on surgery and surgical techniques.

Medical Education: Medical education became institutionalized and provision was made for the study of natural sciences and basic sciences in addition to the study of different aspects of medicine itself. An intimate knowledge of the structure and functions of the human body was held to be very essential for the study and practice of surgery and internal medicine. Most of the information relating to anatomy of Ayurveda is lost, but what is left has been pieced together. It contains detailed descriptions of over 300 bones, 90 tendons, 210 joints, 500 muscles, and so on. 'The formation of the embryo was the subject of long and accurate investigation in the Indian medical texts.' Medical curriculum provided for detailed study of medicinal herbs. Charaka has described, in great detail, the organization of hospitals.

The two well-known centres of medical education in ancient India were the residential universities of Takshashila and Nalanda in north India. These universities provided for well-organized institutional type of training in all aspects of medicineboth theoretical and practical. An interesting feature of these institutions relates to what may be termed as the tutorial cells in which a Guru or preceptor took under him a fixed number of students. This arrangement made it possible for the teacher to bestow personal attention on the students and direct their studies. In other words, 


\section{History of Medicine in India and Burma}

this kind of training combined a well-organized institutional discipline together with the Gurukula or tutorial system. The teacher-pupil ratio of those times corresponds closely to what is recommended by modern medical educators.

State Control of Medical Practice: Before undertaking the practice of medicine or surgery, the medical graduate had to obtain the permission of the king, as the head of the state, after satisfying him that the intending practitioner of medicine and surgery had been fully trained and qualified to do so. This is stated by Sushruta, the ancient Indian surgeon. The state also recognized the importance of preventing quacks and charlatans from practising medicine.

The medical history of ancient India is authenticated, as already stated, mainly in the writings of the two great sages of Indian medicine-Sushruta, the surgeon, and Charaka, the physician. These two teachers headed very advanced Schools of surgery and medicine respectively. According to some scholars, their teachings, especially after the invasion of Alexander the Great, passed to the Greeks and Romans. Hence it is to ancient India that we should look for the origin of modern medicine rather than to Greece and Arabia, as has been the tendency so long.

\section{INDIAN MEDICINE IN MEDIEVAL TIMES}

It is difficult to understand how a system of medicine and of treatment which had reached such heights on the surgical as well as the medical side could, in the course of centuries, have faded away into baser forms. To what extent the Brahmanical ritual was responsible for such a decline it is difficult to say. Religious prejudice against the touching of a corpse could have resulted in making it impossible for the student to learn his anatomy from practical, first-hand dissections. The ancient teachers, Charaka and Sushruta, had themselves dissected the body and counted every big and small bone, besides describing the various organs and tissues of the body. It is stranger still that with the supplanting of Brahmanical religion by Buddhism, there was a further decline in surgery, which practically came to be abandoned; while considerable progress took place, on the other hand, on the medical side with the development of farms for the growth of medicinal plants and herbs, and the founding of hospitals for men as well as animals. But the decline, once started, affected these aspects of medicine also; its various branches passed into the hands of the priests, and charms and amulets began to take the place of drugs and herbs. This compares with the fate that Greek medicine suffered in the dark ages of European history.

Then with the coming of the Muslim conquerors in the sub-continent, the decline became more rapid, as the invaders had brought their own doctors. Whereas the Muslim Hakeems flourished under princely protection in the Moghul Courts, the Hindu Vaidyas held only the lowly office of spell-makers for the poor. Then finally with the advent of the European conquerors and their doctors, the flame of Indian medicine had almost faded out. In spite of all these setbacks, however, Ayurvedic medicine, and to some extent Unani medicine, have persisted in India throughout the centuries, in spite of many of the practitioners of these ancient arts being unqualified men and even quacks, thus bringing disrepute to these systems.

The Portuguese, Dutch, and the British East India Company, who initially came as traders, brought with them their own doctors for service in their ships and factories. 


\section{S. Rao}

To these must be added the French who also brought with them their own physicians and surgeons. By the middle of the eighteenth century, the British East India Company in its battles against the other traders and colonizers, gradually emerged as the dominant European force in the sub-continent. They conquered territories, established an army and introduced a system of medical service in the country, in addition to other governmental measures.

\section{INDIAN MEDICINE DURING THE NINETEENTH CENTURY AND THE FIRST HALF OF THE TWENTIETH CENTURY}

Western medicine in India really began with the promulgation of the Quarantine Act of 1825, which marked the start of the public health movement in India. The Vaccination Act was effected in 1880 and the Birth and Death Registration Act came into being in 1896. This was followed by the Epidemic Diseases Act in 1897, and the Glanders and Farcy Act 1899. Likewise was promulgated the Indian Factories Act in the year 1894 .

With the establishment of the British Government in India and Burma, it became necessary to organize the medical services to provide facilities for medical relief and improvement of public health. These services consisted of the Indian Medical Service, the Central and Provincial Medical Services, and the Subordinate Medical Service. The members of the Indian Medical Service were recruited by a competitive examination in London until 1914, while the staff for the Central, Provincial and Subordinate Medical Services were recruited from India. Medical colleges were started in 1835 at Calcutta, Bombay and Madras in the first instance, and later at Rangoon. Medical schools were started in important centres in the provinces for recruiting the staff to the Subordinate Medical Services.

Medical administration was divided between the Centre and the States. At the Centre, the head of the medical service was the Director-General of the Indian Medical Service, who was the medical adviser to the Central Government. In the provinces, the medical administration was in charge of a Minister responsible to the Provincial Legislature. The technical head of the service was designated the SurgeonGeneral in the three provinces of Bombay, Madras and Bengal, and InspectorGeneral of Civil Hospitals in the others. In the districts the Civil Surgeon was the administrator as well as the Chief Medical Officer. In addition to this, the railways and the defence services had their own medical organizations.

The Director-General of the Indian Medical Service was in charge of medical education and higher medical services in the big cities and towns. It consisted of a civil branch, a research branch, foreign and political branch and a military branch. The officers on the civil side, amounting to a third of the total cadre, were considered as war reserves. By the Government of India Act, passed in 1935, certain selected posts in the civil branch of the Indian Medical Service were reserved only for the European members of the service.

The professional and administrative work done by the members of the civil branch of the Indian Medical Service is well known. Though the members of this service staffed the medical colleges of India for over a century and were heads of the medical laboratories established in different parts of the country, and though the Indian 


\section{History of Medicine in India and Burma}

Research Fund was created as early as 1911-that is, even a year before the establishment of the Medical Research Council in Britain - they added relatively little to the scientific or research side of medicine, barring such noble exceptions as Ronald Ross, Leonard Rogers, Leishmann, Donovan, McCarrison, Short, Megaw, and some others. This was due to the faulty system of selecting the staff for appointment to the teaching medical institutions and research laboratories.

It was in the year 1919 that the departments concerned with public health sanitation and vital statistics were transferred to the provinces. This was the first stage of decentralization of the Health Administration. In 1935, the Government of India Act divided the health activities in the country under three heads, i.e., Federal, Concurrent and Provincial, respectively, under the control of the Central, Central-cumProvincial and Provincial Governments.

During the Second World War, the Health Survey and Development Committee was appointed, and it submitted its report in 1946. This Committee, known as the Bhore Committee after its Chairman, Sir Joseph Bhore, made a very detailed survey of the state of the nation's medical and health services and made recommendations of a far-reaching nature. In 1947, when India attained her Independence, the health of the nation became one of the main concerns of the popular government, wedded to a policy of providing good health, good food and good housing for all its people.

I have purposely made this portion of the paper brief in order to devote more time to the next and more exciting period in the medical history and progress of Independent India.

\section{PROGRESS AFTER INDEPENDENCE IN INDIA (1947 TO DATE)}

In the previous three sections of this paper, I have attempted to very briefly survey the medical history of the sub-continent, extending over thousands of years preceding the attainment of Independence in 1947. The progress after 1947 in the last quarter century has been immense and in several directions. The foundations of modern medical services were, of course, laid by the British; we have built further, expanded greatly in several directions and we are striving hard to catch up with the developed countries in the west. I will first briefly state the position as it existed in 1947.

In 1937, India had one of the highest death rates in the world, being 22.4 per thousand. The hospital beds available were 0.24 per thousand. Even these beds were unevenly distributed being mainly in the hospitals of towns and cities. The villages, of which there are some 700,000 containing about 85 per cent of India's population, had no doctors or nurses and midwives worth speaking of, and village dispensaries were understaffed and under-equipped. There were 7,441 medical institutions out of which only 556 were privately owned. Both the quality and quantity of medical provisioning in the country was totally inadequate for its needs.

In 1946, there were 47,000 doctors on the Medical Register, of which 13,000 were in government employ. The rest were in private practice. There were on an average less than 2 doctors per government institution. Less than 2.5 per cent of villages had doctors practising modern medicine and only about 5 per cent had Vaids or Hakims, i.e. practitioners of Indigenous systems of medicine.

The position of nurses was much worse. There was one nurse to 43,000 of the 


\section{S. Rao}

population, there being 7,000 nurses in all. Like doctors, these were also very unevenly distributed.

On attaining Independence, the Central Government through the Ministry of Health, took over the control of matters relating to health at the national level. It took upon itself the executive responsibility for subjects included in the Union List of subjects. The more important of the former pertained to post-graduate medical education, the promotion of special studies in medicine, including the administration of union agencies and institutes for research, the health scheme for the central government servants and Members of Parliament, port health and quarantine-both sea and air-seamen's welfare and treatment, international sanitary regulations, and India's relationship with the World Health Organization and other foreign government bodies or agencies helping in the promotion of health in India. In relation to matters which are in the State List, the Central Government through the Central Health Council made itself responsible for determining broad policies and plans. It co-ordinates and gives expert medical assistance on matters pertaining to hospitals, medical education, drug control, prevention of food adulteration, etc.

The Ministry of Health performs its functions through a Secretary and the DirectorGeneral of Health Services, who is concerned with technical advice to the Government and with supervising its technical establishments and personnel in Union Territories and elsewhere in India.

A Central Council of Health was statutorily constituted in 1952 to co-ordinate the health programmes of the country. Health Ministers of the States are members of the Council. It is presided over by the Union Minister of Health.

A Central Health Service of officers has been constituted with a view to securing uniformity of standards, pay scales and other conditions of service for medical and public health personnel.

Medical Institutions: Under the various planned programmes, and with aid from foreign countries, bed capacity of the hospitals had expanded to 238,000 by December 1963 , as against 73,000 hospital beds in 1946. Dispensaries increased to 14,000 as against 7,441 in 1946. But in spite of this more than three-fold multiplication of hospital beds in the country, the bed cover has only gone up a few points to about 0.4 per 1,000 , due to the increase in population. A further important feature of postIndependent India is the establishment of Primary Health Centres for taking aid to the villages. By 31 December 1964, 4,192 of these centres had been established, but although these thousands of centres have come into being, 647 of them were still without doctors as late as December 1964. A Primary Health Centre is staffed by one doctor, one sanitary inspector, one health visitor, one compounder and four midwives. It is provided with six beds and caters for the needs of about 66,000 people in the Community Development Block.

The main services provided by these centres are medical care, maternity and child health, health education, control of communicable diseases, environmental sanitation, improvement in collection of vital statistics and family planning. They form the first line in the provision of an integrated medical service for the country.

Contributory Health Scheme and State Employers' Health Insurance Corporations: One of the important achievements was the establishment of the Central Government 


\section{History of Medicine in India and Burma}

Health Scheme, known as the Contributory Health Scheme. Under this pilot plan, every employee of the Central Government makes a fixed monetary contribution proportionate to his salary, every month, in return for which he and his dependants get free medical treatment in special hospitals and dispensaries run by the Centre for the Scheme. Recently, this scheme has been extended to non-government servants and their families, residing in the areas covered by the dispensaries already in existence under the scheme, on payment of an annual contribution.

The Central Government Health Scheme has also been extended to government employees in Bombay in the last year and now covers about 550,000 people in all. For industrial workers, an Employees' State Insurance Corporation has been formed which is eventually intended to cover all perennial factories which use power and employ 20 or more persons. It covers labourers and clerical staff whose monthly emoluments are less than Rs.400. Under this scheme, the employee, the employer, and the Union Government all contribute. The scheme provides for benefits towards sickness and maternity disablement. The modus operandi is somewhat similar to that of the United Kingdom National Health Service. About two million workers have been covered by this scheme.

Although these two schemes are steps in the right direction, in view of the fact that the labour force in India is over 143 million it will be evident that they do not really make an appreciable difference as yet to the problem. Further, the enormity of the task is brought out by the fact that of this working population over 100 million are employed in agriculture, which means that the labour strength is mainly rural in distribution. Unfortunately, this agricultural labour, which constitutes around 72 per cent of the total working force, is not yet provided with even very elementary medical care.

Preventive Medicine and Public Health: In pre-Independent India, public health was a subject separate from curative medicine as far as the administration was concerned. It was administered at the centre by a Public Health Commissioner, who was adviser to the Government in this respect, and in the major provinces, i.e., Madras, Bombay and Bengal, by the Directors of Public Health, who were responsible to their Provincial Governments. In addition, local bodies like the municipalities had their own Health Officers. From this it would appear that the health administration was on an organized basis.

Even though the organization existed, the results were neither satisfactory nor adequate. In 1941, in British India, as separate from the Princely States, the death rate was 21.8 per thousand, infantile mortality 58 per thousand and life expectancy was about 31 years. There was no adequate health service for the industrial workers. Maternity and Child Welfare Centres existed only in the cities. School health service was almost absent.

The foregoing being the case, the new Government set about tackling the huge health problems facing the country in its successive Five Year Plans.

The first of the Five Year Plans gave priorities in matters of health to: (1) provisioning of water supply and sanitation; (2) control of malaria; (3) preventive health care of the rural population; (4) health services for mothers and children; (5) education and training and health education; (6) self-sufficiency in drugs and equipment; (7) family planning and population control. 


\section{S. Rao}

In view of this multipronged attack in tackling India's health problems, Health Administration could no longer be divided into watertight compartments of curative and preventive medicine. They were brought under unified control both at the Centre and in the Provinces.

\section{CONTROL OF DISEASES}

Many measures for the control of diseases were launched on a national scale. Successive plans made increasing provision for these measures.

Malaria: As a result of the National Malaria Eradication Programme which was launched by the Union Ministry of Health with the active participation of the state governments as well as of international bodies such as the U.S. Aid and W.H.O., the incidence of malaria was brought down to 0.12 per cent by August 1964, that is, almost a 98 per cent reduction has been effected in the incidence of malaria.

Tuberculosis: A National Tuberculosis Survey was carried out by the Indian Council of Medical Research, and completed by 1958; it was estimated that there were nearly five million people suffering from the active disease. With the help of international bodies, eradication of tuberculosis was tackled at different points, viz. B.C.G. inoculations, mass miniature radiography, increase of beds for tuberculosis and domiciliary treatment by trained workers.

Leprosy: It is estimated that there are $\mathbf{2 . 5}$ million lepers in India, forming a total of one-third of the leper population of the world. The Government has embarked on a National Leprosy Programme for control of this scourge.

Filaria: It has now been found that filaria is also a national problem, as a recent survey shows that over 122 million people are living in filarial areas of the country. This figure is likely to be increased when further areas are surveyed. The correct method for controlling filaria is the proper disposal of sewage and improvement of sanitary conditions. Short and long term programmes have been launched to control the disease.

Smallpox: A National Smallpox Eradication programme was launched in 1962 in most cities, and up to the end of 1964, 154 eradication units were working, vaccinating and re-vaccinating the population, and it was estimated that nearly 66 per cent of the population have so far been protected. The results of this campaign have been dramatic. In the year $1950-1$, there were 224,510 cases with 57,305 deaths due to smallpox; whereas in $1963-4$, for the same period, the incidence was 26,077 with 7,127 deaths. A remarkable achievement indeed.

Trachoma: A National Trachoma Control Programme was started in 1963, and by the end of 1964,50 field teams were in operation.

Other major projects in the pursuit of bettering the health conditions of the population are: (1) establishment of a National Quarantine Organization in the six major sea ports and four International air ports; (2) steps to prevent food adulteration by appropriate legislation and establishment of Food and Health Laboratories; (3) a national water supply and sanitation programme, which started in 1954; (4) control of drug manufacture by legislation, in order to maintain standards and prevent spurious drugs being put on the market; (5) family planning.

Family Planning: Preventive measures which the Government has taken since 


\section{History of Medicine in India and Burma}

1947 resulted in a saving of life which runs literally into millions. The expectancy of life, which was about 33 years in the decade $1939-40$, rose to 43 years in the decade 1951-60 and in the mid-1960-70 decade the life span was 48 years. This increased survival rate resulted in a population explosion which caused considerable anxiety to the government. Vigorous programmes of birth control were instituted. The matter is so serious that the United Nations have found it necessary to come to India's aid in trying to solve the population problem.

Medical Education and Training: Undergraduate colleges had increased from 38 in 1946 to 81 by 1964. Annual admissions were 10,277 in 1964 as compared with 2,400 in 1946. Postgraduate centres under the aegis of the centre have been established in Delhi, Calcutta, Chandigarh, Calcutta, Hyderabad, Pondicherry, etc.

Several nursing schools and colleges have been opened for the training of nurses, auxiliary nurses, midwives, health visitors and allied personnel. There has been a tremendous increase in the numbers of these, as yet very inadequate for the needs of the country.

Training and research in medical statistics, physiotherapy, and other specialized and ancillary subjects are provided. Laboratory staff training is being actively pursued.

The following Statutory Councils are in operation with well defined objectives: (1) Medical Council of India; (2) Dental Council of India ; (3) India Nursing Council; (4) Pharmacy Council of India; (5) Central Health Education Bureau.

\section{CONCLUSION}

I have attempted to make a brief survey of the history and progress of medicine in the Indian sub-continent over the past five thousand years or so. To compress the medical history of this period of time into the brief space of a single paper is a well-nigh impossible task. The difficulty has been to decide what to include and what to omit.

I would like to emphasize that the history of our civilization, religion and culture are all so composite that every facet of history has a reflection of the other facets. Hence it is that within recent years a new subject designated Indology, has come into being and is a subject of study by both Indian scholars as well as scholars from other countries.

In the preparation of this paper, I have had the valuable advice and guidance of our High Commissioner, His Excellency Dr. Jivraj N. Mehta, who, besides being an eminent physician, has in the past half-century contributed a great deal to the progress of administration and medical aducation in India. I tender my grateful thanks to him for this, and also for graciously permitting me to take part in this Symposium. I also acknowledge the help I have derived from the publications on the subject written by my colleagues and contemporaries in India.

\section{BIBLIOGRAPHY}

Annual Reports, Ministry of Health, Government of India, 1947-1965.

CRAWFORD, D. G., History of the Indian Medical Service, 1600-1913, 2 vols., London, W. Thacker, 1914.

Dwarakanath, C., Swasth Hind-Indian Systems of Medicine, 1961.

Kutumbiah, P., Ancient Indian Medicine, Bombay, Orient Longmans, 1962.

MrhtA, Jivras N., 'Health problems of the Indian Union', Ind. J. med. Sci., 1948, 2 (4).

VakII, Rustom Jal, Our Glorious Heritage, 1696. 